19 Revue d'histoire du XIXe siècle

Société d'histoire de la révolution de 1848 et des

révolutions du XIXe siècle

18 | 1999

Varia

\title{
Recherches sur la question cynégétique en 1848
}

\section{Christian Estève}

URL: http://journals.openedition.org/rh19/146

DOI: $10.4000 /$ rh 19.146

ISSN: $1777-5329$

Publisher

La Société de 1848

Printed version

Date of publication: 1 June 1999

ISSN: 1265-1354

Electronic reference

Christian Estève, «Recherches sur la question cynégétique en 1848 », Revue d'histoire du XIXe siècle [Online], 18 | 1999, Online since 04 September 2008, connection on 19 April 2019. URL : http:// journals.openedition.org/rh19/146; DOI : 10.4000/rh19.146

This text was automatically generated on 19 April 2019

Tous droits réservés 


\title{
Recherches sur la question cynégétique
} en 1848

\author{
Christian Estève
}

\section{ABSTRACTS}

Research on the cynegetic question in $\mathbf{1 8 4 8}$ The 1848 revolution was devoid of traditional cynegetic troubles which marked the previous revolutionary episodes in the countryside. There are numerous and complex explanations for this. It is certain that hunters hoped that the Republic would abolish hunting regulations adopted in 1844. It is difficult to assess the part played by cynegetic problems in the assault against guards and gendarmes, as all forms of violence were characterised with the unique, vague phrase of "forest troubles". Christian Estève also recalls that every hunter owned a gun and that he could be, according to the authorities, a respectable person, or a poacher. This investigation is a careful, meticulous study of conflicts on territory and of electoral stakes, as well as a balanced assessment of abuses.

En 1848, la révolution ne s'accompagne pas des traditionnels troubles cynégétiques qui ont jalonné les précédents épisodes révolutionnaires dans les campagnes. Les explications sont multiples et complexes. Il est certain que les chasseurs espèrent de la République l'abolition du code de la chasse mis en place en 1844. Il est aussi difficile de déterminer la part des problèmes cynégétiques dans les agressions contre les gardes et les gendarmes, les violences étant regroupées sous le vocable flou de "troubles forestiers ". Christian Estève rappelle également que tout chasseur est détenteur d'un fusil et qu'il peut être, selon les autorités, un homme respectable et de l'autre côté de la barricade, un braconnier. C'est à une étude minutieuse et attentive des conflits territoriaux, des enjeux électoraux, et à une évaluation peut être nuancée des exactions que nous convie cette enquête. 
INDEX

Mots-clés: 1848 , Chasse 